\title{
Using Podcasts to Improve Second Language Comprehension in Iranian Language Classrooms
}

\author{
Mohammad Davoudi (Corresponding author) \\ Assistant professor of TEFL, Department of English Language and Literature \\ Hakim Sabzevari University, Sabzevar, Iran \\ E-mail: davoudi2100@gmail.com \\ Mojtaba Rezaei \\ MA holder in TEFL, Department of English Language and Literature \\ Hakim Sabzevari University, Sabzevar, Iran \\ E-mail: Moji_naji2219@yahoo.com
}

Received: March 13, 2016 Accepted: April 7, 2016 Published: May 1, 2016

doi:10.5296/jse.v6i2.9176 URL: http://dx.doi.org/10.5296/jse.v6i2.9176

\begin{abstract}
The present study aims at investigating the influence of podcasts (POD) on language comprehension of Iranian pre-intermediate EFL learners. An Oxford Placement Test (OPT) was administered to 60 male and female university students. The participants were considered as pre-intermediate learners and were divided into two groups (one experimental group and one control group). During the fifteen sessions of the treatment, thirty podcasts were presented to the two groups. The experimental group received just the audio file of the POD, and the control group received a different treatment which was the transcript file of the same audio podcast file of the experimental group. The results of the t-tests revealed that there was no significant difference in language comprehension scores across the posttest between two groups. Based on the interview results after the post-test, all of the participants (100\%) agreed that both audio and the transcripts (written texts) were useful for them and claimed that it is a good method of improving language comprehension.
\end{abstract}

Keywords: Podcasts, Transcript Texts, Language Comprehension, Audio files. 


\section{Introduction}

For a long time, learning a second or foreign language has been considered as an important part of the human life. An important part of learning a second or foreign language is language comprehension (Cebeci, \&Tekdal, 2010). According to Lawlor \& Donnelly (2010), learning a language has a mutual relationship with language comprehension. Based on their conceptualization, everyone can learn a second language through exposure to the second language (video, audio, or texts file). They believe that exposure to the appropriate text allows the learner to read in the second language which is a fundamental part in developing language comprehension.

In Iran, mobile devices, CD-ROMs, multimedia computer labs, and the World Wide Web, are playing an important part in language learning (AbediKargiban \& Kaffash, 2011). As the curriculum of the students does not provide many opportunities to develop language comprehension skill for the learners in their pre-university level of education, they will face many difficulties in their higher education. As classrooms are mainly conducted in Persian and students do not have many opportunities to be in contact with native speakers and are not exposed to authentic files of their target language, podcasts can help these students fulfill this gap easily (Dolati \& Seliman, 2011).

In last eight years, using podcasts have become very popular and considered as an important part of language learning and teaching (Zamari, Adnan, Idria, \&Yusef, 2011). At least in the US, several years ago, it was claimed that, incorporating e-learning (short audio and video files) into the traditional teaching mechanisms would have a great effect in the life of most EFL students (Özdener, and Güngör, 2010). Almost every one (EFL learners) in our community now uses mobile phones without being aware of the usefulness of these devices. The easy access to the Internet and the availability of a huge number of applications make mobile devices more fashionable among young people. Many researchers have already mentioned in their studies that using mobile phones provide opportunities for the learners to be in contact with native people of the target language (Popova and Edirisingha, 2010). Using these portable technologies makes it easier for language learners, and they can expand their vocabulary, improve their speaking and listening skills and develop their language comprehension through using their mobile phone when and where they want (Lawlor\& Donnelly, 2010).

Using podcasts as a supplementary task can help teachers to provide authentic, up-to-date and interesting audio materials on topics the students are interested in (Dale, 2007). Morrissey (2012) described that through using authentic materials in the classrooms, teachers can bring the real atmosphere into the class, and podcasting technology stimulates students and exposes them to the target language and culture and support students in their language learning.

Evans (2008) asserts that learning can also take place when the learner is not at a fixed place, through listening to audio podcasts while they are walking. Therefore, learners can direct their learning through listening to podcasts at their own speed and in their free time (Al Qasim and Fada, 2013). For improving language comprehension skills, the language teachers can 
find a number of podcasts through the internet and expose students to them. If the podcasts are chosen according to the learner's level of comprehension, they will have a number of advantages for the second language learners (Sabet, \&Mahsefat, 2012). According to Chi \& Chan (2011), when learners listen to podcasts and read along its text, they improve both their listening and language comprehension. This activity effectively bridges the gap for their both formal and informal second language problems.

As Trinkle (2008) points out, when learners listen to the audio files for a period of time, their listening skill will improve. It is considered to be a useful listening comprehension strategy. Trinkle (2008) also commented that reading texts is a useful remedy for language comprehension problems. It is also generally accepted that second or foreign language learners who are good at reading comprehension usually have higher level of language comprehension (Abdous, Facer, \& Yen, 2012). Learners can overcome their second language learning difficulties through exposure to the appropriate level of texts and video or audio files (Chan, Chen, \& Döpel, 2011). By choosing the files which are in line with learners' language proficiency levels, learners can overcome their language comprehension problems.

Krashen (2004) emphasizes that students should receive comprehensible extensive input to build their language proficiency. If the students have a routine plan of receiving language data through movies, audio files and reading texts, they can gradually develop their language knowledge (Popova, and Edirisingha, 2010). In this way, they will have a good supply of useful vocabulary and grammar usage that help them to improve their language comprehension (Krashen, 1993). Many years have passed from the time that Maxim (2002)proposed reading texts as a new style of teaching and learning new language and many studies have been conducted around the world ever since. For example, in Asia, Chan, Chen, \&Döpel, 2011), and in Europe, Pigada \& Schmitt (2006), Tudor and Hafiz (1989), have conducted many studies in the field of extensive reading. By reading the previous studies related to extensive reading, teachers can be very helpful to their students. They can guide them to use their time reading extra reading text as a self-study and increase their level of language comprehension. However, owing to the improvement of technology, the students can be advised to listen or watch the authentic materials in their computers or their mobile phones (Constantine, 2007).

Today, language teachers and researchers have realized the important role of language comprehension in different pedagogical tasks. There is no doubt that most second or foreign language learners and teachers are well aware of the fact that learning a second or foreign language requires exposure to authentic input (AbediKargiban \& Kaffash (2011). Researcher are also becoming more and more convinced that being exposed to comprehensible input is very important for the improvement in language comprehension.

In Asian countries, language comprehension is generally given little emphasis in the education curriculum (Dolati, \&Seliman, 2011). The situation is the same in Iran as an Asian country. Although the emphasis on English teaching in Asian countries is on the four language skills, their language comprehension is not at a good level (Dolati, \& Seliman, 2011). 
Many studies which have been conducted around the world have confirmed the positive effect of visual and auditory files on language learning and teaching (Kurtz, Fenwick \& Ellsworth, 2011; Ractham\& Zhang, 2010). To the best of the researchers' knowledge, no study in the context of Iran has implemented a visual and auditory program course at the university level in order to examine the effectiveness of podcasts versus transcript files of the same podcasts on EFL language comprehension. Therefore, the present study strives to investigate the effectiveness of the employment of podcasts on the improvement of language comprehension of the EFL students who are majoring in English as a Foreign Language.

In spite of the expansion in the amount of empirical research on language comprehension, however, consensus is lacking over the issue of what the most efficient means are to promote effective language comprehension. We intend to check whether exposure to podcasts, whether the audio file or transcript file, leads to a better language comprehension and results in an improvement in language proficiency. Additionally, while many studies on the effectiveness of podcasts have been conducted in L1 settings, little attention has been paid to the effect of podcasts and reading texts on expanding L2 language proficiency and comprehension (McMinn, 2008). And yet, researching the effect of podcasts (audio file) and its transcripts on language comprehension is important as it may influence pedagogical decisions with regard to recommendations of incorporating audio files and their transcripts in the learner's curriculum courses.

The main goal of this study is to investigate the influence of podcasts and their transcripts on language comprehension of language learners. By exposing language learners to audio file and their transcripts, we will examine the effectiveness of each kind of files on language learner's performance. Hence, this research project intends to achieve the following objectives:

(1) To analyze the impact of audio podcasts files on English language comprehension

(2) To analyze the effect of podcasts transcript files on English language comprehension

In an attempt to fill in the gaps identified in the previous section, the present study looks into the effects of podcasts and their transcripts on language comprehension of pre-intermediate Iranian EFL students. The present study attempts to find answers to the following research questions:

1. Does the use of podcasts affect the language comprehension of Iranian EFL learners?

2. Does the use of podcasts transcript files affect the language comprehension of Iranian EFL learners?

3. What is Iranian EFL learners' attitude towards podcasts and its effect on language comprehension?

\section{Literature Review}

Lum (2006) was interested in the processes required for acquiring information from the video and audio files, which are available for second language learners, and the way they analyze 
these files. According to Lum (2006), watching or listening to the authentic files is an enjoyable great personal activity; from which enjoyment can be obtained in which one can become engaged.

Sze (2006) defined podcasts as an effective activity related to language comprehension. Sze's (2006) ideas are considered as the former versions of the present conceptualization of podcasting that defines podcasts as more than watching or listening just for pleasure. They express the view that learners should have both pleasure and learning objectives in using these files (podcasts). Understanding these files needs the learner's previous information about the different elements of the text such as syntactic and semantic parts, which play an important role to predict meaning (Rezapour, Gorjian, \&Pazhakh, (2012).

$\mathrm{Ng}$ 'ambi (2008) believes that podcasts form an interaction between listeners and the contexts. Listening is a kind of thinking and it is inseparable from other elements like purpose and feeling of the listeners. McMinn, (2008) specified the listening process as a psycholinguistic guessing game, because it involves predicting, testing and verifying. Podcasting is considered as a complicated cognitive activity (Abt\& Barry, 2007) because it requires a great deal of particular information which must be received or mastered and too many processing strategies which must be used until they become mechanical. Therefore, both podcasts and the transcripts are useful ways of improving one's language proficiency and language comprehension. The popular point of view toward podcasts involves recognizing words and general understanding (Lawlor\& Donnelly, 2010). Listening which is considered as especially synonymous with language comprehension is a complicated behavior, which includes conscious and unconscious use of different strategies and approaches to create ad meaningful concept that the teller or the actors are supposed to intend (Lawlor\& Donnelly, 2010).

In a study conducted by Abdous, Facer, \& Yen (2012), the participants' language comprehension and language proficiency were improved after using podcasts for five weeks. Ina study by Edirisingha\& Salmon (2007), the improvement in the language comprehension and general information of the participants was shown. Abdous, Facer, \& Yen (2012) conducted a study with University students of Canada. The subjects participated in a Korean program on podcasts on language comprehension for about 4 weeks. At the end of the experiment, the learner's general understanding and their language comprehension improved significantly. Campbell (2005) found an improvement in language comprehension and language proficiency of high school students in Spain who had participated in a Chinese extensive reading program. Constantine (2007) reported an improvement in general understanding and positive attitude toward podcasts as a way of improving second language through new technology among Taiwanese University students in Hawaii.

Lum (2006) as well as Ng'ambi (2008) examined the effect of podcasts on foreign language learners. The participants were a large number of graduated students of Brazil. They found a correlation between listening to podcasts and their improvement in language proficiency. Richards (2006) started a study to find whether there is a correlation between video podcasts and reading improvement or not. His participants were Cantonese speaking university students who took part in this case study. The result showed an improvement in their reading 
comprehension. Then, he continued their study for another 4 weeks. In this study, the participants took parts in listening pretest to check their listening ability before starting the program. In the end, and after taking part in a podcast listening program for about 4 weeks, the participants took part in listening test again for checking their improvement. The result showed that the two variables had a positive correlation.

Another study which was conducted by Al Qasim \& Fada (2013) shows the improvement of oral proficiency of the subjects through exposure to audio podcasts. They reported the positive effect of podcasts on learner's improvement. In addition to these results, the gain in oral proficiency was reported by Kennedy \& Trofimovich (2008), gains in reading comprehension by Cebeci \& Tekdal (2010) gains in oral proficiency by Campbell (2005) and gains in writing by Evans (2008). Sabet \& Mahsefat (2012) found that when listening to the audio files of the reading texts in French, those students who had access to written and pictorial annotations remembered the whole story and remembered the passage better than those listening the texts alone. They suggest that this confirms Cebeci \& Tekdal (2010) theory of Multimedia Learning.

Cebeci \& Tekdal (2010) investigated the use of listening podcasts by 342 Japanese students of English at three national universities through a questionnaire. The results showed that the Japanese student's language proficiency improved. Whereas the participants used authentic files daily, they seldom consulted dictionaries. Popova \& Edirisingha (2010) pointed out that the student's communication strategies extended after the treatment. The majority of the students evaluated the transcript files highly due to their usefulness and practicality; in particular, high school students evaluated the transcript texts more highly than college students, possibly they can analyze syntax and lexis more carefully. Although the audio podcasts and transcript files contained the same amount of information, high school students felt that the podcasts was not useful. Özdener \& Güngör(2010) explained this by the podcasts interface design. Since podcasts were rather difficult for the high school students, students were forced to understand the texts while they were listening.

Therefore, students felt that they did not contain sufficient information although it actually did.

According to Lawlor \& Donnelly (2010), although the results of previous studies show the positive effect of podcasts on different aspects of FL/SL learning, there is not a clear criteria for measuring; therefore, the results are suggestive rather than definitive (Lawlor\& Donnelly, 2010). Lawlor \& Donnelly (2010) believes that researchers can not control all the variables correctly and their methodologies are not fixed, sometimes they change it in order to get this agreeable result. According to the previous studies and the real nature of podcast files, the efficiency of different aspects of podcasts needs to be studied more. Finding which one (audio podcasts or the transcript file) is more helpful for that learners is very significant.

\section{Method}

\subsection{Participants}

The participants of this study consisted of sixty $(\mathrm{N}=60)$ male and female university students, ranging in age from 18 to 20 , who were in their first semester. They were all 
majoring in English teaching in Sari, a city in northern part of Iran. All of them were native speakers of Persian. They had learned English for about six years prior to their university studies. The reason why university students were selected was that they had passed the university entrance examination in English translation and had enough knowledge to listen to pre-intermediate listening files and read texts (transcripts). Although the participants were homogeneous in terms of their common experience in English learning, an Oxford Placement Test (OPT) was administered to them in order to determine their level of general English proficiency. The students whose placement test scores were one standard deviation above and below the mean were selected as pre-intermediate group. Furthermore, the participants took part in a pre-test (PET) in order for the researchers to evaluate their level of comprehension before the treatment.

\subsection{Design of the study}

In this study, the researcher used simple random sampling, which is a probability sampling procedure. Because of the randomization and providing maximum control of extraneous variables, the researcher used quasi-experimental design. Participants were assigned to the two experimental groups by random assignment after the use of OPT. Then, the participants in the experimental groups took part in Preliminary English Test to assess their prior language comprehension before the treatment. Next, they were exposed to the treatment part of the study for a specified time, after which the two groups were measured on the dependent variable in the form of post-tests.

\subsection{Research Instruments}

To find answers to the research questions of the study, three tests were used: first, the participants took part in an Oxford Placement Test (OPT).Then, they had Preliminary English Test (PET) as a pre-test to determine the learners' level of language comprehension at the start, and the third test was the post-test for each group to assess the effect of podcast audio files and the transcript files on language comprehension of the participants. The treatment part of the present study consists of audio Podcast files, podcast transcript files, and open-ended interviews. The podcasts used in this study were selected from the English as a Second Language (ESL) Podcasts. These podcast series were chosen based on their popularity among listening comprehension researchers (Constantine, 2007). At the end of the treatment, an open-ended interview was administered in order to elicit the participants' attitudes toward podcasts and transcript files. The researcher interviewed forty participants of the study one by one at the assigned time after the post-test. The interviewees had to answer questions about podcasts and the transcript files.

\subsection{Procedure}

The researcher conducted this study in Adib University, Sari, Iran. The participants of the study were majoring in English translation. They were in their first semester. They had some reading background and were assumed to have sufficient readiness for listening audio podcast files and read the transcripts. Their textbook for their first semester was Interaction 1. Given the conditions of the two classes, the researchers decided to run the study in their regular 
reading classes as a complimentary part of their reading course. In this experimental study, the researchers played the role of teachers in order to introduce the podcast files for the experimental groups. All two classes were held successfully at Adib University.

The experimental procedure consisted of three stages: Pretests, Treatments, and Post-tests. One week before the study, a standardized English proficiency test (Preliminary English Test) was administered to 60 participants who were randomly divided into two groups based on their OPT. The researcher conducted the pre-test on the $1^{\text {st }}$ of October at 8 o'clock. There were 6 questions in the reading PET test (pre-test), and the exam time was about 45 minutes. The students were supposed to read the reading passage in each section and answer the comprehension questions after the text.

In the first week of the study, which was on the $1^{\text {st }}$ of October, all the participants took part in the pretest which consisted of reading texts. Then, they were randomly assigned to two groups. From the second week of the study, the real treatment started. In the second session, the researcher explained what podcasts and the transcripts really are for both experimental groups. In both groups, the participants were briefed on podcasts and the transcripts, which formed the goals of the study. The researchers provided the podcasts and the transcripts for both groups.

In the first experimental group, the participants received audio podcast files as a treatment. In this group, the researcher supplied 30 audio podcasts for the participants. In the control group, the participants received the transcript files of the same audio file texts as a treatment. In this group, the researcher supplied 30 transcript file texts for the participants. In session 17, which was on $9^{\text {st }}$ of December, the participants of the experimental groups were ready for post-test. The post-test was administered forthe two experimental groups (who passed treatment courses). The participants were selected, took part in the pretest and the treatment, and then they took part in the posttest (the seventeenth session).

\section{Results and Discussion}

To accomplish the purposes of the present study, 60 students from a public university in Sari, Iran, who were considered as a pre-intermediate based on Oxford Placement Test (OPT) level guide, participated in this study. After the pretest, the two groups received the 8 weeks treatments (listening to audio podcasts for the experimental group and reading transcript texts for control group). The post-test of the participants was the modified version of the PET-Test. The data in this study were gathered with the aim of finding out whether or not using audio podcasts, as compared with transcript text files, has any effect on the language comprehension of pre-intermediate EFL students.

A t-test was run to see whether significant (non-chance) differences can be found between two means or not. The results of the pre-test performance of the participants are shown in Table 4.1. 
Table 4.1. Descriptive Statistics for Pretest Results on proficiency test

\begin{tabular}{|l|l|l|}
\hline & POD1 & TRANSCRIPT1 \\
\hline Mean & 50.66 & 51.30 \\
$\mathrm{~N}$ & 30 & 30 \\
Std. Deviation & 9.749 & 10.031 \\
Minimum & 36.00 & 30.00 \\
Maximum & 65.00 & 72.00 \\
\hline
\end{tabular}

As it could be seen in Table 4.1, the mean scores of the first (Podcast group) and the second group (transcript group) are 50.66 and 51.30 respectively. As the table shows, the mean difference size is small among the two groups, but in order to see whether the mean difference is small or big at the beginning of the study, the researcher conducted a t-test in order to compare the mean scores.

Table 4.2 Analysis of the Pre-Test Mean

Independent Samples Test (podcast group vs. transcript group)

\begin{tabular}{|c|c|c|c|c|c|}
\hline & $\begin{array}{ll}\text { Levene's Test } \\
\text { Variances }\end{array}$ & Equality 0 & st for $E$ & lality of $\mathrm{M}$ & eans \\
\hline & $\mathrm{F}$ & Sig. & $\mathrm{t}$ & $\mathrm{df}$ & Sig.(2-tailed) \\
\hline Group $1 \& 2$ & .064 & .802 & $\begin{array}{l}-.248 \\
-.248\end{array}$ & $\begin{array}{c}58 \\
57.953\end{array}$ & $\begin{array}{l}.805 \\
.805\end{array}$ \\
\hline
\end{tabular}

As Table 4.2 shows, the probability value is bigger than the level of significance, $\mathrm{P}=0.805>.05$. Thus, it can be concluded that there is no significant difference between the mean scores of PET test between the participants in extensive group (podcast) and control group (transcript) on their pre-test at the beginning of the treatment. Although many factors can have an influence on the result of each study, the result of the present study is in line with some of the previous studies (Lawlor\& Donnelly, 2010; Cebeci\&Tekdal, 2010) that claimed that podcasts can have the same influence on reader's language comprehension as the written texts.

\subsection{Normality test}

Testing the normality of the data is one of the statistics that determine the normal distribution of the variables in a study. Therefore, we used SPSS in order to assess normality of the data, whether the students are arranged homogeneously in the groups, or not. 
Table 4.3. Tests of Normality

\begin{tabular}{|l|l|l|l|c|c|r|}
\hline & \multicolumn{2}{|l|}{ Kolmogorov-Smirnov $^{\mathrm{a}}$} & \multicolumn{2}{l|}{ Shapiro-Wilk } \\
\cline { 2 - 8 } & Statistic & $\mathrm{df}$ & Sig. & Statistic & df & Sig. \\
\hline POD 1 & .118 & 30 & $.200^{*}$ & .924 & 30 & .398 \\
Transcript 1 & .098 & 30 & $.200^{*}$ & .976 & 30 & .415 \\
\hline
\end{tabular}

Based on the result of the Table 4.3, the Sig. value of the normality Test is greater than 0.05 , which indicates that the data is normal and the students were distributed perfectly in two groups.

\subsection{Results of Posttest for the Control and Experimental Groups}

The results obtained from the post-test are presented in Table 4.4. Moreover, another independent sample t-test was run in order to see whether the treatment given to the experimental groups had any effects on their language proficiency and to see if the participants in these groups performed significantly different on their post-test. The result of the second independent sample t-test is presented in Table 4.6.

Table 4.4. Descriptive Statistics for Post-test Results on proficiency test

\begin{tabular}{|c|c|c|c|l|l|}
\hline & GROUPS & $\mathrm{N}$ & Mean & Std. Deviation & Std. Error Mean \\
\hline Post-test group & 1.00 & 30 & 60.1333 & 10.36151 & 1.89174 \\
$1 \& 2$ & 2.00 & 30 & 56.0333 & 9.04961 & 1.65222 \\
\hline
\end{tabular}

The mean and standard deviation of the experimental group's pre- and post-tests were calculated using SPSS 20. The researchers attempted to know whether the audio podcast files had any effect on language comprehension of the participant (group 1) at the end of the treatment. In order to examine the differences and see whether they were significant, a paired sample t-test was applied. The results demonstrated in Table 4.5 indicate that the mean difference between the first and second podcasts score (the experimental group), which were measured at the time of the pre-test and post-test, was significant. Therefore, it indicates that the podcast files had effects on participant's language comprehension.

Table 4.5. Paired Samples Test

\begin{tabular}{|ll|l|l|l|l|l|}
\hline & \multicolumn{3}{|c|}{ Paired Differences } & & & S. \\
\cline { 3 - 6 } & & Mean & Std. Deviation & & \\
(2-tailed)
\end{tabular}


Table 4.6. Independent Samples Test (podcast group (1) vs. transcript group(2))

\begin{tabular}{|l|c|c|c|c|c|}
\hline \multirow{2}{*}{} & \multicolumn{2}{|c|}{$\begin{array}{c}\text { Levene's Test for } \\
\text { Equality of Variances }\end{array}$} & \multicolumn{3}{|c|}{ t-test for Equality of Means } \\
\cline { 2 - 6 } & F & Sig. & T & df & Sig.(2-tailed) \\
\hline & 1.899 & .174 & 1.632 & 58 & .108 \\
Post-test group 1 \& 2 & & & 1.632 & 56.969 & .108 \\
\hline
\end{tabular}

As the independent sample t-test (Table 4.6) shows, the probability value is bigger than the level of significance, $\mathrm{P}=.108>.05$. Thus, it can be concluded that there is not a significant difference between the mean scores of PET test between the participants in group 1 (podcast group) and group 2 (transcript group) on their post-test. Their mean scores were 60.13 and 56.03 respectively (Table 4.7 ). Therefore, the the first null hypothesis stating that engagement in audio podcast program does not affect the language comprehension of Iranian EFL learners, is rejected.

\subsection{Comparing the Pre- and post-tests}

By analyzing the participants' performance (Table 4.7) on both pre- and post-tests, the researchers came to the conclusion that in the two groups, the participants performed better in their post-test as their mean scores indicates. It indicates that audio podcasts had a positive effect on the language comprehension of the participants, and comparing the two t-values of the experimental groups (table 4.8) indicates that the participants in the podcast group performed slightly better than the transcript group.

Table 4.7. Experimental and control groups' pre- and post- test result

\begin{tabular}{|c|c|c|c|c|}
\hline & POD1 & POD2 & TRANSCRIPT1 & TRANSCRIPT2 \\
\hline Mean & 50.6667 & 60.1333 & 51.3000 & 56.0333 \\
$\mathrm{~N}$ & 30 & 30 & 30 & 30 \\
Std. Deviation & 9.74974 & 10.36151 & 10.03150 & 9.04961 \\
\hline
\end{tabular}


Table 4.8. Paired Samples Test

\begin{tabular}{|l|c|c|c|c|c|c|}
\hline & \multicolumn{3}{|c|}{ Paired Differences } & $\mathrm{t}$ & $\mathrm{df}$ & Sig.(2-tailed) \\
\cline { 2 - 5 } & Mean & Std. Deviation & $\begin{array}{c}\text { Std. Error } \\
\text { Mean }\end{array}$ & & & \\
\hline POD1 - POD2 & -9.46667 & 3.95434 & .72196 & 13.112 & 29 & .000 \\
$\begin{array}{l}\text { Transcript1- } \\
\text { Transcript 2 }\end{array}$ & -4.73333 & 2.59885 & .47448 & 9.976 & 29 & .000 \\
\hline
\end{tabular}

\subsection{Interview Results}

In this section, the researchers administered an interview with 40 participants (20 participants from podcast group and 20 participants from transcript group). The questions on the interview inquired about the participants' audio file listening habits as well as their attitude and viewpoints towards podcasting. All the interviewees (100\%) in both podcast and transcript groups had the same point of view. All of them considered the files useful and had positive attitudes toward them. 14 participants $(70 \%)$ in the first experimental group answered that exposure to these kinds of texts are related to their future career and they can get various kinds of information. 8 students $(40 \%)$, in the first group, pointed that they felt anxious at the beginning of the study when they did not understand all the words while they listened to the audio files. However, in the end, they could listen to different audios without anxiety although they did not know some of the meanings of the new words. About $89 \%$ of the participants in the second group (transcript group) claimed that it was an enjoyable experience for them.

All the participants in the two groups pointed that they intended to continue using both types of files, because these files helped them to improve their language comprehension. 15 students from the first group commented that their accuracy in speaking improved a lot and helped them to understand English better. About 17 of the participants (85\%) in the first group mentioned that podcasts are one of the best ways for improving language learning in general. All of the participants unanimously agreed that they had a great experience during the treatment and they enjoyed the files. It was claimed, on the part of the participants, that using podcasts along with the transcripts in the classroom creates an enjoyable and relaxed learning environment. All of the participants in the podcast group liked the files, but they mentioned that using the audio files and the transcripts simultaneously will help them more. And most of the participants $(85 \%)$ in the transcript group claimed that using the technology and listening to the audio files will have greater effect on their language learning. Reporting on their experience of using podcast files, students were unanimous in reporting that the podcasts were very useful for them

\subsection{Discussion}

Unlike Kennedy \& Trofimovich (2008) studies, in which students did not necessarily believe in the effectiveness of podcasts as compared the reading texts for learning EFL, students in the present study showed interest in dealing with podcast files after their treatment period. Furthermore, the findings of this study are in line with previous research 
findings (Lawlor\& Donnelly, 2010) concerning the effect of podcasts and the written transcripts in enhancing language comprehension. The results are also similar to those of Lum (2006) and Ng'ambi (2008) who showed that some L2 learners decide to use the extensive reading texts when they have language comprehension problems. One of the reasons often reported by students is the time involved in listening audio podcast files, referring to the fact that the listener is free and can listen anytime and anywhere for pleasure. The ease of listening to these files may encourage the learners to continue listening for a long time. Moreover, the data of the study together with the results of Al Qasim \& Fada (2013) suggest that, in most cases, combining both files reinforces language learning. The beneficial effect of this combination may lie in the richness of language comprehension.

One possible explanation for this finding is the fact that students enjoyed both files during the treatment and the mean scores provided evidence that these files improved students' language proficiency to a great extent. This view is also expressed inRezapour, Gorjian \& Pazhakh (2012). They found that podcast and their transcripts had great influence on improving relationships between language comprehension and students' reading proficiency.

Moreover, the findings of the interview part of the present study are similar to those of Shim, Shropshire, Sungmin\& Harris (2007) and Constantine (2007)who suggested that motivation and attitude are probably the most frequently catch-all terms for explaining the success or failure of virtually any complex task. It is easy to assume that success in any task is due simply to the fact that someone is motivated and have a good attitude. It is easy in second language learning to claim that a learner will be successful with the proper motivation. Such claims are of course not erroneous, because countless studies and experiments in human learning have shown that motivations and attitudes are the key to learning (Richards, 2006). Generally speaking, the use of podcasts inside or outside the classroom tends to make the learners more proficient in their second language learning. However, one quantifiable benefit to use these files outside the classroom is that student can manage their time and listen to their audio files.

\section{Conclusion}

This study investigated the effect of audio podcast files on language comprehension of sixty university EFL learners at the pre-intermediate level. The result of the present study shows the impact of podcasting technology on students' comprehension outcomes. It examined the significance of using this technology as a motivational factor for the students to listen more to the audio files. The results showed that podcasting had the potential to help learners, to improve their English skills in general (McMinn, 2008) and to change the ways teachers and students interact (McMinn, 2008).

It was also found that there are no significant differences between these two files in language comprehension of EFL learners. As a result, it proved to be a beneficial learning tool, since these files (podcasts and the transcripts) enhance language learning in general. Students who were involved in this study did not mention having any problems 
with using the audio podcast technology. The students were satisfied with the process of the present study and noted that they had a great experience taking part in this research. This study also confirms that exposure to audio podcasts is part of language learning which supports the power of listening in improving the language comprehension (Campbell, 2005), and enhancing reading proficiency. Therefore, the study provides evidence for integrating the extensive reading texts in the curriculum of language learning and teaching.

In conclusion, the result of this study supports our intuition about the effectiveness of using podcasts to improve language comprehension in English classrooms. As the participants mentioned in their interview, podcasts can improve learners' English skills such as listening comprehension, language comprehension, reading comprehension and even their speaking. What it means is that English teachers need to integrate podcasts into their class to develop language learners' language comprehension by the content of context from a variety of voices. To do so, English teachers need to be familiar with the technological tools and their purpose.

\section{References}

Abdous, M., Facer, B. R., \& Yen, C. (2012). Academic effectiveness of podcasting: A comparative study of integrated versus supplemental use of podcasting in second language classes. Computers \& Education, 58, 43-52. http://dx.doi.org/10.1016/j.compedu.2011.08.021

AbediKargiban, Z., \& Kaffash, H. R. (2011).The effect of e-learning on foreign language students using the student's attitude. Middle-East Journal of Scientific Research 10(3), 398-402.

Abt, G., \& Barry, T. (2007).The quantitative effect of students using podcasts in a first year undergraduate exercise physiology module. Bioscience Education, 10(1), 1-9. http://dx.doi.org/10.3108/beej.10.8

Al Qasim, N., \& Al Fadda, H. (2013). From Call to Mall: The effectiveness of podcast on EFL higher education students' listening comprehension. English Language Teaching, 6(9), 30.

Campbell, G. (2005). There's something in the air: Podcasting in education. EDUCAUSE Review, 40(6), 32-47.

Cebeci, Z., \& Tekdal, M. (2010).Using podcasts as audio learning objects. Interdisciplinary Journal of Knowledge and Learning Objects, 2, 7-57.

Chan, W. M., Chen, I. R., \& Döpel, M. (2011). Podcasting in foreign language learning: Insights for podcast design from a developmental research project. In M. Levy, F. Blin, C. Bradin Siskin \& O. Takeuchi (Eds.), WorldCALL: Global perspectives on computer-assisted language learning (pp. 19-37). London: Routledge.

Chi, S. W., \& Chan, W. M. (2011). Learning beyond the classroom: Language podcast as supplementary learning material. Ubiquitous Learning, 3(2), 21-39.

Constantine, P. (2007). Podcasts: another source for listening input. The Internet TESL Journal, 13(1). Retrieved from http://iteslj.org/Techniques/Constantine-PodcastListening.html 
Dale, C. (2007). Strategies for using podcasting to support student learning.Journal of Hospitality, Leisure, Sport and Tourism Education, 6(1), 49-57. http://dx.doi.org/10.3794/johlste.61.155

Dolati, I. R., \& Seliman, S. (2011). An investigation on Iranian students' weaknesses in spoken English.Journal of Edurpes, 1(1), 94-99.

Edirisingha, P., \& Salmon, G. (2007).Pedagogical models for podcasts in higher education [online] http://hdl.handle.net/2381/405 Accessed 20.09.2007.

Evans, C. (2008). The effectiveness of m-learning in the form of podcast revision lectures in higher education. Computer and Education, 50, 491-498. http://dx.doi.org/10.1016/j.compedu.2007.09.016

Kennedy, S., \& Trofimovich, P. (2008). Intelligibility, comprehensibility, and accentedness of L2 speech: The role of listener experience and semantic context. Canadian Modern Language Review, 64(3), 459-489. http://dx.doi.org/10.3138/cmlr.64.3.459

Krashen, S. D. (1993). The power of reading: Insight from the research. Englewood. CO: Libraries Unlimited, INC.

Krashen, S. D. (2004). Free voluntary reading: New research, applications, and controversies. Proceedings of the Fifth Pan-Asian Conference on Language Teaching at FEELTA2004, Vladivostok, June 24-27, 16-19.

Kurtz, B., Fenwick, J., \& Ellsworth, C. (2011). Using podcasts and tablet PCs in Computer Science, ACMSE, March 23-24, Winston Salem, NC, USA.

Lawlor, B., \& Donnelly, R. (2010). Using podcasts to support communication skills development: A case study for content format preferences among postgraduate research $\begin{array}{llll}\text { students. } \quad \text { Computers } \& \text { Education, } & \text { 54(4), }\end{array}$ http://dx.doi.org/10.1016/j.compedu.2009.09.031

Lum, L (2006). The power of podcasting. Retrieved November 26, 2007, from Diverse Issues in Higher Education Web site: http://diverseeducation.com/artman/publish/article_5583.shtml.

Maxim, H. H. (2002). Extensive and intensive reading in an EAP setting. English for Specific Purposes, 16, 47-60.

McMinn, S. W. J. (2008). Podcasting possibilities: Increasing time and motivation in the language learning classroom. Retrieved from http://www.eife-1.org/publications/proceedings/ilf08/contributions/improving-quality-of-learn ing-with-technologies/McMinn.pdf.

Morrissey, J. (2012). Podcast steering of independent learning in higher education. AISHE-J (Spring 2012) 21-45.

Ng'ambi, D. (2008). Podcasts for reflective learning. In G. Salmon \& P. Edirisingha (Eds.), Podcasting for learning in universities (pp. 132 - 145). Berkshire, England: Open University Press. 


\section{Al Macrothink}

Journal of Studies in Education

ISSN 2162-6952

2016, Vol. 6, No. 2

Özdener, N., \&Güngör, Y. (2010). Effects of video podcast technology on peer learning and project quality. Procedia-Social and Behavioral Sciences, 2, 2217-2221. http://dx.doi.org/10.1016/j.sbspro.2010.03.311

Pigada, M., \& Schmitt.N.(2006). Second language reading and incidental vocabulary learning.Angles on the English-Speaking World, 4, 11-23.

Popova, A., \& Edirisingha, P. (2010). How can podcasts support engaging students in learning activities? Procedia-Social and Behavioral Sciences, 2, 5034-5038. http://dx.doi.org/10.1016/j.sbspro.2010.03.816

Ractham, P., \& Zhang, X. (2010). Podcasting in academia: A new knowledge management paradigm within academic settings. In Proceedings of the 2006 ACM SIGMIS CPR conference (pp. 314-317).

Rezapour, E. Gorjian, B., \& Pazhakh, A. R. (2012). The effect of Moodle and Podcast's instruction on vocabulary development among pre- intermediate EFL learners. AITM, 2(2), $32-40$.

Richards, J. C. (2006). Communicative language teaching today. Retrieved August 1, 2014, from: http://www.professorjackrichards.com/pdfs/communicative-language-teachingtoday

Sabet, M. K., \& Mahsefat, H. (2012). The impact of authentic listening materials on elementary EFL Learners' Listening Skills.International Journal of Applied Linguistics \& English Literature, 1(4), 216-229.

Sze, P. M.-M. (2006). Developing students' listening and speaking skills through ELT podcasts.Education Journal, 34(2). Retrieved from http://podcasterpaul.wikispaces.com/file/view/06_EJ_ELTPodcasts.pdf

Trinkle, C. (2008). Listening comprehension leads to reading success. School Library Media Activities Monthly, 24, 43-45.

Tudor, I., \& Hafiz, F. M. (1989).Word knowledge and vocabulary instruction. Poster session presented at International Conference on Engineering Education.

Zamari, Z., Adnan, A., Idria, Sh., \& Yusef, J. (2011). Students' perception of using online language learning materials.Procedia-Social and Behavior Sciences, 67, 611-620. http://dx.doi.org/10.1016/j.sbspro.2012.11.367 